\title{
Disaster, unmitigated
}

\section{An oil slick will not re-engage the public with environmental issues, warns Colin Macilwain, but it might lead to a saner US energy policy.}

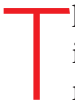
he economist Paul Krugman suggested in his New York Times column earlier this month that the BP oil leak in the Gulf of Mexico could provide the flagging environmental movement with the renewed impetus it so badly needs.

The modern movement, he pointed out, gained a great deal of momentum from a fire on the Cuyahoga River in Cleveland, Ohio, on 22 June 1969. Legend holds that the sight of the blazing river fuelled public support for measures including the creation of the powerful Environmental Protection Agency by Richard Nixon in 1970, and the passage of the Clean Water Act two years later.

Environmentalists have long since lost the power, in the United States and elsewhere, to achieve legislative success on anything like that scale. And it will take more than an environmental disaster on the shores of the southern states to restore that kind of influence.

The river fire reflected the chronic urban pollution being experienced by a great many people at that time - at home, at work and on holiday. The conundrum for environmental activists and scientists today is that the issues that matter most no longer affect voters in developed countries so immediately.

Having dealt successfully with the flagrant issues of filthy water and urban smog, environmentalists have turned to global trends that pose exis-
"The global approach to environmental issues has violated the axiom that all politics is local."

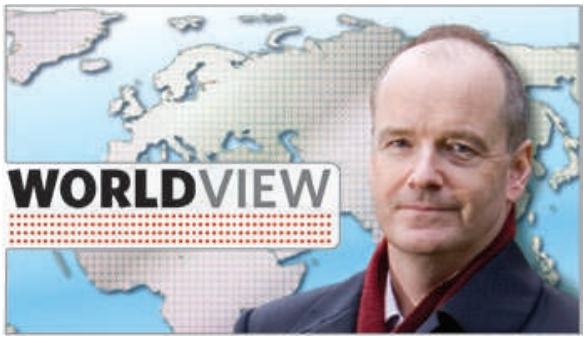

set up to confront environmental challenges.

The result is that environmental issues consistently rank close to bottom on the list of voters' priorities. In an Opinion Research Corporation poll for CNN in March, for example, "energy and environmental policies" were identified as "the most important issue" in congressional elections by just $2 \%$ of voters.

In retrospect, 1992's Earth Summit in Rio de Janeiro was something of a high-water mark for the political salience of green issues. There, world leaders sought to catalyse international action to meet grave environmental threats by agreeing to the Framework Convention on Climate Change and the CBD.

Instead of galvanizing public concern, this global approach has diluted it by violating the axiom that all politics is local. Take the CBD. On 10 May, it released its third Global Biodiversity Outlook report, summarizing the progress made by the parties to the convention. It makes grim tential threats to our world. But the two leading problems - climate change and biodiversity conservation - come across to many people as mere abstractions.

\section{Remote control}

Environmental activism in the United States has changed in other ways. By moving on from neighbourhood-based, grass-roots campaigning to a reliance on expensive court actions - an approach that has, admittedly, yielded successes - environmental groups have distanced themselves from the ordinary people whose interests they seek to serve.

This sense of remoteness pervades not just the leadership of the main environmental activist groups, it also clings to the scientific and semi-scientific bodies, such as the Intergovernmental Panel on Climate Change and the Convention on Biological Diversity (CBD), reading: despite some local successes, none of 21 subsidiary targets to the CBD's 2002 goal of achieving a "significant reduction" in the rate of biodiversity loss by 2010 has been met. Ten of 15 indicators tracking biodiversity show negative trends.

Ahmed Djoghlaf, who runs the CBD's secretariat in Nairobi, Kenya, hopes the findings will get world leaders to acknowledge the importance of biodiversity. "This report makes it clear why their response to the economic crisis must take on board the biodiversity agenda," he says. A day of biodiversity talks is planned for heads of state at the United Nations in September, followed by the expected endorsement of a new strategic plan at the next conference of the 193 parties to the CBD in Nagoya, Japan, in October.

But asked what the CBD is doing to build public support for faster action to conserve biodiversity, Djoghlaf points to the designation of 2010 as the International Year of Biodiversity (it's also the International Day for Biodiversity this Saturday, 22 May). It is very hard to see such sterile designations registering with the wider public, however.

In the United States, the Senate has failed even to ratify the CBD, signed by President Bill Clinton in 1993, because public pressure on senators to vote for it is too weak to overcome the mild objections of the drug industry to its call for bioprospectors to share patent rights with local people.

\section{Troubled waters}

The oil leak in the Gulf has certainly elicited a sharper short-term political response than the slow-burn issue of biodiversity conservation has ever managed. Arnold Schwarzenegger, the governor of California, was soon in full Terminator mode. "All of you have seen, when you turn on the television, the devastation in the Gulf. That will not happen here in California," he said, reversing his previous support for fresh oil drilling off Santa Barbara.

The weather, together with the success or otherwise of BP's well-capping efforts, will determine the extent to which the Gulf spill will ingrain itself on the public consciousness. If it makes its mark, the spill could shift US energy policy, forcing the administration to push both renewable sources and nuclear power even harder than it has already. So far, President Barack Obama's policy response has been measured: he remains committed to offshore drilling, but is tightening its regulation.

However, the spill is unlikely to reinvigorate an environmental movement whose interests and mode of operation remain too far removed from mainstream politics to match the influence that was fleetingly enjoyed four decades ago.

Public indifference to environmental issues, if left unchecked, could eventually undermine support for scientists in the plethora of subdisciplines, from ecology to atmospheric physics, that are now strongly oriented towards meeting global environmental threats.

There has always been a lively debate (originally in ecology, and now more widely) about whether a scientist can mix objectivity with advocacy. It's not an argument that needs to be resolved: it depends on the outlook and temperament of the scientist. However, those researchers who do feel comfortable with advocacy need to spend more time on the ground, talking to real people about why their work matters.

Colin Macilwain is based in the United Kingdom.

e-mail: cfmworldview@gmail.com

See go.nature.com/ILx8PC for more columns. 